\title{
PENGARUH MEDAN MAGNET EXTREMELY LOW FREQUENCY (ELF) TERHADAP NILAI PH BUAH ANGGUR HITAM
}

\author{
Enik Wasiah Niati'1), Sudarti'1), Yushardi'1) \\ 1)Program Studi Pendidikan Fisika, FKIP, Universitas Jember, Jember, Jawa Timur, Indonesia \\ Corresponding author: Enik Wasiah Niati. \\ E-mail : enik070898@gmail.com
}

\section{Diterima 28 April 2021, Direvisi 05 Mei 2021, Disetujui 05 Mei 2021}

\begin{abstract}
ABSTRAK
Medan magnet ELF merupakan gelombang elektromagnetik dengan frekuensi sampai $300 \mathrm{~Hz}$ dan tergolong sebagai radiasi non ionizing. Penelitian ini menggunakan desain randomized subject post-test only control group design, dengan pembagian dua kelompok subjek penelitian dipilih secara acak. Penelitian ini bertujuan untuk mengetahui pengaruh paparan medan magnet ELF .terhadap nilai $\mathrm{pH}$ buah anggur hitam. Dalam penelitian ini ada dua kelompok yaitu kelompok kontrol dan eksperimen, dimana kelompok eksperimen diberi perlakuan medan magnet ELF intensitas $300 \mu \mathrm{T}$ dan $500 \mu \mathrm{T}$ selama 60 ' dan 120' untuk masing-masing intensitas. Analisa data nilai pH buah anggur menggunakan SPSS 24 yaitu uji kruskal wallis. Berdasarkan hasil analisa data didapat bahwa medan magnet ELF intensitas $300 \mu \mathrm{T}$ dan $500 \mu \mathrm{T}$ berpengaruh terhadap nilai $\mathrm{pH}$ buah anggur hitam. Nilai $\mathrm{pH}$ kelompok kontrol lebih tinggi dari kelompok eksperimen. Hal ini disebabkan karena intensitas di bawah 500 $\mu \mathrm{T}$ menekan pertumbuhan mikroorganisme pembentuk asam didalam buah angggur hitam.
\end{abstract}

Kata kunci: medan magnet ELF; analisa data; $\mathrm{pH}$.

\begin{abstract}
The ELF magnetic field is an electromagnetic wave with a frequency of up to $300 \mathrm{~Hz}$ and is classified as non-ionizing radiation. This study used a randomized subject post-test only control group design, with the division of two groups of research subjects randomly selected. This study aims to determine the effect of exposure to ELF magnetic fields on the $\mathrm{pH}$ value of black grapes. In this study, there were two groups, namely the control and experimental groups, where the experimental group was treated with an ELF magnetic field with an intensity of $300 \mu \mathrm{T}$ and $500 \mu \mathrm{T}$ for 60 'and 120' for each intensity. The data analysis of the $\mathrm{pH}$ value of grapes used SPSS 24, namely the kruskal wallis test. Based on the results of data analysis, it was found that the ELF magnetic field with the intensity of $300 \mu \mathrm{T}$ and $500 \mu \mathrm{T}$ had an effect on the $\mathrm{pH}$ value of black grapes. The $\mathrm{pH}$ value of the control group was higher than the experimental group. This is because the intensity below $500 \mu \mathrm{T}$ suppresses the growth of acid-forming microorganisms in the black grapefruit.
\end{abstract}

Keywords: ELF magnetic field; data analysis; $\mathrm{pH}$.

\section{PENDAHULUAN}

Gelombang elektromagnetik merupakan gelombang yang dihasilkan dari medan listrik dan medan magnet yang kuat. Gelombang elektromagnetik dapat merambat walaupun tanpa medium. Medan listrik dan medan magnet memiliki arah yang tegak lurus dengan sistem koordinat $x, y$, dan $z$ seluruh daerah dibagi ke dalam dua daerah yang tegak lurus dengan sumbu $x$ dan sejajar dengan $y-z$ (Hugh D Young, 2012).

Radiasi dalam istilah fisika adalah suatu perambatan energi ke lingkungan. perbedaan efek radiasi terjadi karena frekuensi, jarak paparan terhadap terhadap sumber, lama pemaparan, panjang gelombang. Perpaduan medan listrik dan medan magnet yang berosilasi disebut radiasi elektromagnetik, yang mana radiasi tersebut dapat merambat menembus ruang dan membawa energi ke lingkungan. menurut (Bafaai, 2004) menyatakan bahwa radiasi gelombang elektromagnetik terbagi menjadi dua kelompok, yaitu frekuensi sangat rendah (extremely low) dan frekuensi sangat tinggi (extremely high).

Anggur kaya akan vitamin, mineral, karbohidrat dan senyawa fitokimia. Anggur tergolong dalam buah yang rentang mengalami pembusukan dan tidak tahan lama (Coniwanti et al., 2014).

Kerusakan buah di pengaruhi karena adanya aktivitas difusi gas, baik kedalam maupun keluar melalui inti sel. Lama kelamaan buah mengalami kerusakan, sehingga tidak 
dapat di konsumsi lagi. Maka Maka dari itu perlu adanya usaha untuk menghambat proses pembusukan pada bahan makanan agar daya simpannya lebih panjang (Hilma et al., 2018).

Pengawetan dengan menggunakan medan magnet dengan Intensitas yang rendah, dapat memperpanjang daya simpan buah tanpa mengurangi kandungan nutrisi pada buah yang di papar dengan menggunakan medan magnet tersebut. Selain untuk buah buahan paparan medan magnet ELF dapat di manfaatkan sebagai pengawet dalam bidang pangan. Maka dari itu peneliti banyak yang memanfaatkan paparan medan magnet ELF khususnya dalam bidang pangan yaitu (sudarti, S Bektiarso, SHB Prastowo, T Prihandono, Maryani, 2020) menunjukkan bahwa perlakuan medan magnet ELF intensitas $300 \mu \mathrm{T}$ selama 45' dapat mengoptimalkan perkembangbiakan Lactobacillus secara drastis dalam proses fermentasi kopi luwak buatan. Berdasarkan penelitian (putri ma'rufiyanti, sudarti, 2017), menyatakan bahwa paparan selama 90' berpengaruh terhadap ketahankan kadar vitamin C buah tomat. Sedangkan penelitian (Mina et al., 2018) menyatakan bahwa intensitas $900 \mu \mathrm{T}$ dengan lama paparan 2x30 dan $2 \times 45$ berpengaruh terhadap ketahanan kualitas fisik buah anggur merah. Penelitian (Ridawati et al., 2017)menyatakan bahwa intensitas $100 \mu \mathrm{T}$ dan $300 \mu \mathrm{T}$ dengan lama paparan selama 5', 15' dan 25' berpengaruh terhadap $\mathrm{pH}$ susu fermentasi. (Andika kristinawati, 2016)menunjukkan bahwa dosis efektif untuk menurunkan $\mathrm{pH}$ dan kelembaban pada krim keju adalah pemaparan medan magnet ELF $100 \mu \mathrm{T}$ selama 5 menit. (sudarti et all, 2020), menunjukkan bahwa intensitas $730 \mu \mathrm{T}$ terhadap pamaparan radiasi medan magnet ELF selama 2×30' dapat menurunkan bakteri pada ikan bandeng. (sudarti, 2018) pemaparan medan magnet ELF dengan intensitas $100 \mu \mathrm{T}$ selama 5 ' merupakan dosis yang efektif untuk aktivasi S. thermophilus, L. lactis, dan L. acidhopilus pertumbuhan bakteri. Berdasarkan penelitian (Sudarti, 2016) menyatakan bahwa efektivitas dosis ELF dengan intensitas $646,7 \mu \mathrm{T}$ selama 30 menit terbukti dapat menurunkan populasi Salmonella pada gado-gado, sehingga radiasi medan magnet ELF dijadikan sebagai alternative sterilisasi pangan segar dengan biaya yang murah dan juga terjaga keamanannya.Maka dari itu penelitian ini bertujuan untuk mengetahui pengaruh medan magnet ELF terhadap nilai $\mathrm{pH}$ buah anggur hitam.

\section{METODE PENELITIAN}

Penelitian ini dilakukan bulan April 2021, alat penghasil medan magnet bertempat di
Laboratorium Fisika Lanjut Gedung 3 Prodi Pendidikan Fisika Fakultas Keguruan dan IImu Pendidikan Universitas Jember. Jenis penelitian ini menggunakan desain randomized subject post-test only control group design, dengan pembagian dua kelompok subjek penelitian dipilih secara acak. Alat-alat yang digunakan dalam penelitian ini yaitu EMF Source sebagai alat penghasil medan magnet, EMF tester untuk mengukur intensitas yang diinginkan, $\mathrm{pH}$ meter untuk mengetahui nilai $\mathrm{pH}$ buah anggur hitam, mortal dan alu untuk menghaluskan buah anggur hitam, gelas beker sebagai tempat melarutkan buah anggur dan aquades. Bahan yang digunakan yaitu aquades, plastic cling wrap.

Sampel dalam penelitian ini yaitu buah anggur hitam yang dibeli dari pedagang yang bertempat di Arjasa. Buah anggur ini merupakan buah anggur yang biasanya sering dikonsumsi oleh masyarakat. Penentuan sampel dilakukan secara acak yaitu $1 \mathrm{~kg}$ buah anggur untuk kelompok kontrol dan $4 \mathrm{~kg}$ buah anggur hitam kelompok eksperimen, kelompok eksperimen dengan dipapar medan magnet. Kelompok eksperimen terbagi menjadi dua yaitu kelompok-1 dengan intensitas $300 \mu \mathrm{T}$, dan kelompok ke-2 dengan intensitas $500 \mu \mathrm{T}$. Setiap kelompok terdiri dari $2 \mathrm{~kg}$ buah anggur hitam, kemudian diberi perlakuan medan magnet ELF 60' dan 120'. Sedangkan untuk kelompok kontrol dibiarkan di ruangan terbuka tanpa sinar matahari. Perhitungan nilai $\mathrm{pH}$ buah anggur hitam dilakukan setiap 3 hari sekali setelah pemaparan, yaitu hari ke $3,6,9,12$, dan 15, Pengukuran dilakukan pengulangan sebanyak 5 kali.

Pengukuran nilai $\mathrm{pH}$ buah anggur dilakukan secara langsung menggunakan alat $\mathrm{pH}$ meter. Terlebih dahulu menyiapkan sampel buah anggur kemudian dicuci agar bersih dari pestisida, lalu dibungkus menggunakan plastic cling wrap. Sampel dipapar medan magnet ELF

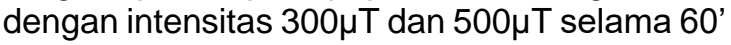
dan 120'. Sedangkan untuk kelompok kontrol dibiarkan di suhu ruang. Dalam pengukuran $\mathrm{pH}$ diambil 5 buah anggur hitam atau setara dengan 20gr. Kemudian dihaluskan menggunakan mortal dan alu, setelah itu di tambahkan aquades $2 \mathrm{ml}$ sebagai pelarut. Mencelupkan alat $\mathrm{pH}$ meter kedalam larutan buah anggur kemudian mencatat hasil pengukuran $\mathrm{pH}$ dan dilakukan pengulangan sebanyak 5 kali.

\section{HASIL DAN PEMBAHASAN}

Pengukuran nilai $\mathrm{pH}$ buah anggur hitam dilakukan di Laboratorium Fisika Lanjut Program Studi Pendidikan Fisika FKIP Universitas Jember. Berdasarkan hasil 
penelitian ini di dapatkan data rata-rata nilai $\mathrm{pH}$ buah anggur hitam sebagai berikut :

Tabel 1. Nilai rata-rata $\mathrm{pH}$ buah anggur hitam

\begin{tabular}{ccccccc}
\hline Kel. & \multicolumn{7}{c}{ Nilai pH hari ke- } \\
& $\mathbf{0}$ & $\mathbf{3}$ & $\mathbf{6}$ & $\mathbf{9}$ & $\mathbf{1 2}$ & $\mathbf{1 5}$ \\
\hline Kontrl & 3,3 & 3,77 & 3,27 & 3,66 & 3,57 & 3,52 \\
\hline $\mathrm{E}_{3.6}$ & 3,3 & 3,74 & 3,46 & 3,64 & 3,53 & 3,59 \\
\hline $\mathrm{E}_{3.12}$ & 3,3 & 3,65 & 3,4 & 3,6 & 3,56 & 3,59 \\
\hline $\mathrm{E}_{5.6}$ & 3,3 & 3,75 & 3,4 & 3,59 & 3,63 & 3,53 \\
\hline $\mathrm{E}_{5.12}$ & 3,3 & 3,63 & 3,38 & 3,58 & 3,6 & 3,51 \\
\hline
\end{tabular}

Berdasarkan tabel 1. dapat diketahui nilai rata-rata $\mathrm{pH}$ buah anggur untuk kelompok kontrol dan kelompok eksperimen. Masing masing perbedaan nilai rata-rata $\mathrm{pH}$ dapat diketahui melalui diagram batang berikut ini :

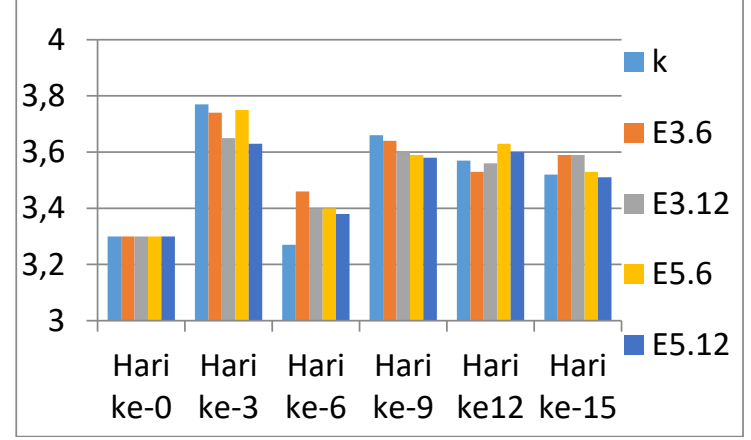

Gambar 1. Grafik nilai pH buah anggur hitam

Berdasarkan Gambar 1. grafik diagram rata-rata nilai $\mathrm{pH}$ buah anggur hitam di hari ke3 untuk kelompok kontrol lebih tinggi dari pada kelompok eksperimen dengan nilai pH 3,77, namun di hari ke-6 setelah pemaparan intensitas $300 \mu \mathrm{T}$ 60' memiliki nilai $\mathrm{pH}$ lebih tinggi yaitu 3,46 . Di hari ke-6 nilai $\mathrm{pH}$ buah anggur baik kelompok kontrol maupun kelompok eksperimen mengalami penurunan yang drastis. Di hari ke-9 nilai $\mathrm{pH}$ buah anggur mengalami kenaikan, dimana kelompok kontrol memiliki nilai $\mathrm{pH}$ yang lebih tinggi dari pada kelompok eksperimen yaitu sebesar 3,66. Di hari ke-12 nilai $\mathrm{pH}$ tertinggi pada intensitas $500 \mu \mathrm{T}$ 60' dengan nilai 3,63. Di hari ke-15

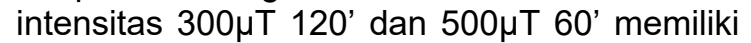
nilai pH yang sama tinggi yaitu 3,59 . Berdasarkan hasil penelitian tersebut kelompok kontrol memiliki nilai pH maksimum dari pada kelompok eksperimen. Hal ini berdasarkan penelitian sari et al, 2018 yang menyatakan bahwa intensitas $300 \mu \mathrm{T}$ terjadi penurunan nilai $\mathrm{pH}$, penurunan $\mathrm{pH}$ terendah pada menit ke-15. Kristinawati et al, 2016 menyatakan bahwa intensitas $300 \mu \mathrm{T}$ dengan lama paparan 5 menit berpengaruh dalam meningkatkan perkembangbiakan bakteri laktosa dalam proses pembuatan cream cheese serta berpengaruh dalam penurunan $\mathrm{pH}$ dan kadar air. Sehingga berdasarkan penelitian sebelumnya intensitas $300 \mu \mathrm{T}$ belum mampu untuk menaikkan nilai $\mathrm{pH}$, sehingga nilai $\mathrm{pH}$ buah anggur untuk kelompok kontrol memiliki selisih yang lebih tinggi. Namun berdasarkan Tabel 1. Nilai $\mathrm{pH}$ buah anggur kelompok eksperimen intensitas $300 \mu \mathrm{T}$ dan $500 \mu \mathrm{T}$ dengan lama paparan 60 menit memiliki selisih nilai $\mathrm{pH}$ buah anggur hitan yang lebih tinggi dari pada intensitas $300 \mu \mathrm{T}$ dan $500 \mu \mathrm{T}$ dengan lama paparan 120 menit. Hal ini dapat di simpulkan bahwa intensitas $300 \mu \mathrm{T}$ dan $500 \mu \mathrm{T}$ dengan paparan selama 60' dapat meningkatkan nilai $\mathrm{pH}$ anggur hitam.

Peningkatan dan penurunan nilai $\mathrm{pH}$ terjadi karena penghambatan aktivitas metabolisme pembentukan asam. Protein yang berada di dalam inti sel menjadi rusak dikarenakan pemberian medan magnet ELF. Medan magnet dapat menembus ruang atau benda-benda di sekitarnya. Protein didalam inti sel berperan untuk pertumbuhan dan metabolisme menjadi rusak, sehingga rusaknya protein dalam sel dapat menghambat metabolisme dalam sel. Oleh karena itu bakteri penghasilkan senyawa asam akan terganggu (Ma'rufiyanti, 2014).

Langkah selanjutnya yaitu menggunakan analisa data SPSS untuk mengetahui ada tidaknya pengaruh nilai $\mathrm{pH}$ buah anggur hitam antara kelompok kontrol dengan kelompok eksperimen. Sebelumnya kita menggunakan uji normalitas untuk mengetahui data berdistribusi normal atau tidak. Karena hasil penelitian $\mathrm{pH}$ buah anggur hitam tidak berdistribusi normal, sehingga menggunakan uji non parametris yaitu mengunakan uji Kruskall Wallis untuk mengetahui perbedaan antara kelompok kontrol dengan kelompok eksperimen secara keseluruhan. Berikut tabel uji kruskal wallis :

Tabel 2. uji kruskal wallis nilai $\mathrm{pH}$ buah anggur hitam

\begin{tabular}{|c|c|c|c|c|c|c|}
\hline \multicolumn{7}{|c|}{ Test Statistics ${ }^{a, b}$} \\
\hline & 0 & 3 & 6 & 9 & 12 & 15 \\
\hline Chi- & & 22,4 & 22,0 & 22,5 & 22,65 & 20,86 \\
\hline Square & ,467 & 45 & 32 & 80 & 1 & 6 \\
\hline $\mathrm{df}$ & 4 & 4 & 4 & 4 & 4 & 4 \\
\hline $\begin{array}{l}\text { Asymp. } \\
\text { Sig. }\end{array}$ & ,977 &, 000 & ,000 & ,000 &, 000 & ,000 \\
\hline a. Krusk & Nallis & & & & & \\
\hline b. Group & Varia & e: kel & ok & & & \\
\hline
\end{tabular}

Tabel 2. uji kruskal wallis nilai $\mathrm{pH}$ buah anggur secara keseluruhan pada hari ke-0 sebelum pemaparan medan magnet ELF memiliki Asymp.Sig. 0,977, artinya yaitu nilai Asymp. Sig. 0,977>0,05, yang berarti Ho diterima dan $\mathrm{Ha}$ ditolak. Maksudnya yaitu tidak ada perbedaan nilai $\mathrm{pH}$ buah anggur hitam antara kelompok kontrol dengan kelompok eksperimen dihari ke-0.

Pada tabel $\mathrm{pH}$ hari ke3 hingga hari ke15 setelah pemaparan nilai Asymp.Sig. 0,000. Artinya yaitu nilai Asymp. Sig. 0,000 < 0,05, yang berarti Ha diterima dan Ho ditolak. 
Maksudnya yaitu ada perbedaan nilai $\mathrm{pH}$ buah anggur hitam antara kelompok kontrol dengan kelompok eksperimen intensitas $300 \mu \mathrm{T}$ 60'. $300 \mu \mathrm{T} 120$ ', $500 \mu \mathrm{T}$ 60', dan $500 \mu \mathrm{T}$ 120' di hari ke3 setelah pemaparan hingga hari ke 15 setelah pemaparan.

\section{SIMPULAN DAN SARAN}

Berdasarkan hasil analisa data paparan medan magnet ELF, kelompok kontrol memiliki selisih nilai $\mathrm{pH}$ yang lebih tinggi dari pada kelompok eksperimen $\mathrm{Hal}$ ini di karenakan medan magnet dapat menembus sel bakteri pembentuk asam, sehingga protein di dalam sel menjadi rusak. Dengan rusaknya protein dapat menghambat proses metabolisme, sehingga aktivitas bakteri pembentuk asam menjadi terhambat. Hasil uji statistik kruskal wallis nilai pH buah anggur hitam nilai Asymp. Sig. 0,000 $<0,05$ yang berarti terdapat perbedaan nilai $\mathrm{pH}$ buah anggur hitam antara kelompok kontrol dan kelompok eksperimen intensitas $300 \mu \mathrm{T}$ dan $500 \mu \mathrm{T}$.

\section{UCAPAN TERIMAKASIH}

Terimaksih saya ucapkan kepada kepala laboratorium fisika lanjut dan temanteman yang telah membantu dalam meyelesaikan penelitian ini. Dan saya ucapkan terimaksih banyak bagi yang mau memberikan saran dan masukan, sehingga penelitian ini dapat di jadikan rujukan bagi penelitian selanjutnya.

\section{DAFTAR RUJUKAN}

Andika kristinawati, sudarti. (2016). Pengaruh Eksposur Medan Magnet Frekuensi Sangat Rendah ( ELF ) terhadap Proses Membuat Keju Krim. T leBaSltCh:, TEonwviarrodnsmTehnetE

TeenrdgeydAUse Of Basi, 181-183.

Bafaai, U. (2004). Polusi dan pengaruh medan elektromagnet terhadap kesehatan masyarakat. Jurnal Teknik Simetrika, 2.

Coniwanti, P., Pertiwi, D., Mutia Pratiwi, D., \& Raya Palembang-Prabumulih Ogan Ilir, J. (2014). Pengaruh Peningkatan Konsentrasi Gliserol Dan Vco (Virgin Coconut Oil) Terhadap Karakteristik Edible Film Dari Tepung Aren. Teknik Kimia, 20(2), 17-24.

Hilma, Fatoni, A., \& Sari, P. (2018). Potensi Kitosan sebagai Edible Coating pada Buah Anggur Hijau ( Vitis vinifera Linn). Jurnal Penelitian Sains, 20(1), 25-29.

Hugh D Young. (2012). College Physics, 9th Edition.

Ma'rufiyanti, P. (2014). PENGARUH PAPARAN MEDAN MAGNET ELF ( Extremely Low Frequency ) $300 \mu \mathrm{T}$ DAN $500 \mu \mathrm{T}$
TERHADAP PERUBAHAN KADAR VITAMIN C DAN DERAJAT KEASAMAN ( pH ) PADA BUAH TOMAT Mahasiswa Program Studi Pendidikan Fisika Dosen Pendidikan Fisika FKIP Universitas Jember Program. Jurnal Pendidikan Fisika, 3, 277-284.

Mina, N. M., Sudarti, \& Yushardi. (2018). Pengaruh medan magnet ELF terhadap kapasitansi buah anggur merah. Journal Pendidikan Fisika, 3(2), 216-220.

putri ma'rufiyanti, sudarti, agus abdul gani. (2017). Digital Digital Repository Repository Universitas Universitas Jember Jember Bacillus cereus Digital Digital Repository Repository Universitas Universitas Jember Jember. Jurnal Pendidikan Fisika, 3 no.3, 277-284.

Ridawati, S., Sudarti, \& Yushardi. (2017). Pengaruh Paparan Medan Magnet Extremely Low Frequency (ELF) terhadap $\mathrm{pH}$ Susu Fermentasi. Seminar Nasional Pendidikan Fisika 2017, 24 SEPTEMBER 2017, 2(September), 1-5.

sudarti, S Bektiarso, SHB Prastowo, T Prihandono, Maryani, R. H. (2020). Mengoptimalkan pertumbuhan lactobacillus pada proses fermentasi kopi luwak buatan menggunakan medan magnet frekuensi sangat rendah ( ELF ) Mengoptimalkan pertumbuhan lactobacillus pada proses fermentasi kopi luwak buatan menggunakan medan magnet frekuensi. Jurnal Fisika: Seri Konferensi.

sudarti. (2018). Analisis dosis efektif paparan medan magnet frekuensi sangat rendah ( ELF ) terhadap Analisis dosis efektif paparan medan magnet frekuensi sangat rendah ( ELF ). Seri Konferensi IOP: IImu Dan Teknik Material.

Sudarti. (2016). en Pemanfaatan Medan Magnet Extremely Low Frequency ( ELF ) sebagai Alternatif Sterilisasi Salmonella typhimurium Di Gado-Gado. Procedia Pertanian Dan IImu Pertanian, 9(medan magnet ELF), 317-322. https://doi.org/10.1016/j.aaspro.2016.02. 140

sudarti et all. (2020). Potensi pemanfaatan medan magnet ELF untuk proses pengawetan bandeng ( chanos chanos ) Potensi pemanfaatan medan magnet ELF untuk proses pengawetan bandeng ( chanos chanos ). Jurnal Fisika: Seri Konferensi. 